\title{
Areawide management of fall armyworm, Spodoptera frugiperda (Lepidoptera: Noctuidae), using selected cover crop plants
}

\author{
Robert L. Meagher Jr. ${ }^{*} \mathbb{0}$, Rodney N. Nagoshi', Shelby J. Fleischer², John K. Westbrook ${ }^{3}$, David L. Wright ${ }^{4}$, \\ J. Bradley Morris ${ }^{5}$, James T. Brown ${ }^{1,6}$ and Amy J. Rowley ${ }^{1}$
}

\begin{abstract}
Background: Fall armyworm, Spodoptera frugiperda (J. E. Smith) is a migratory moth that annually migrates northward each spring from sites in southern Florida and southern Texas. This caterpillar pest feeds on and damages row, turf and vegetable crops in the eastern and central U.S. Before migrating in spring, it feeds on cover crops in central and eastern Florida and expands its populations. Our objective was to use multi-year studies to compare fall armyworm populations that develop in cover crop plants.
\end{abstract}

Methods: A series of field experiments and a laboratory feeding study were conducted to compare infestation and feeding and of fall armyworm on different cover crop plants. Field experiments had plots planted with corn (Zea mays L.), sorghum-sudangrass [Sorghum bicolor (L.) Moench], a standard cover crop in Florida, and two alternative cover crops, sunn hemp (Crotalaria juncea L.) and cowpea [Vigna unguiculata (L.) Walpers spp. unguiculata]. Another trial compared populations in sorghum-sudangrass and in mixtures of sorghum-sudangrass with buckwheat (Fagopyrum esculentum Moench) or pearl millet (Cenchrus americanus (L.) Morrone). Fall armyworm larvae were fed and allowed to develop on different sunn hemp germplasm in a laboratory trial.

Results: Field populations of fall armyworm were highest on corn, followed by sorghum-sudangrass. Sunn hemp and cowpea had larval populations 70-96\% less than on sorghum-sudangrass, suggesting replacement of this cover crop with either plant species might help reduce areawide populations of resident or migratory fall armyworm. Larvae collected from cover crop plots had parasitism levels that averaged 30\%, with Chelonus insularis (Hymenoptera: Braconidae) emerging as the most commonly-collected species. Larval feeding on different sunn hemp germplasm lines resulted in no difference in weight gain.

Conclusions: Replacing sorghum-sudangrass with sunn hemp varieties or germplasm should be acceptable as a replacement cover crop for areawide management of fall armyworm.

Keywords: Sunn hemp, Crotalaria, Cowpeas, Vigna, Noctuidae

*Correspondence: rob.meagher@usda.gov

${ }^{1}$ Insect Behavior and Biocontrol Research Unit, USDA-ARS CMAVE, 1700 SW 23rd Dr., Gainesville, FL 32608, USA

Full list of author information is available at the end of the article

\section{Introduction}

Fall armyworm, Spodoptera frugiperda (J. E. Smith), is a native caterpillar pest of row, turf, and crops in the eastern and central U.S. (Braman et al. 2000; Luttrell and Mink 1999; Nuessly et al. 2007; Souza et al. 2013). This noctuid is a neotropical insect that annually migrates northward each spring from sites in southern original author(s) and the source, provide a link to the Creative Commons licence, and indicate if changes were made. The images or other third party material in this article are included in the article's Creative Commons licence, unless indicated otherwise in a credit line to the material. If material is not included in the article's Creative Commons licence and your intended use is not permitted by statutory regulation or exceeds the permitted use, you will need to obtain permission directly from the copyright holder. To view a copy of this licence, visit http://creativecommons.org/licenses/by/4.0/. The Creative Commons Public Domain Dedication waiver (http://creativeco mmons.org/publicdomain/zero/1.0/) applies to the data made available in this article, unless otherwise stated in a credit line to the data. 
Florida (Pair et al. 1986; Westbrook and Sparks 1986) and southern Texas (Pair et al. 1991; Raulston et al. 1986). Migratory haplotypes separating fall armyworm populations from Florida and Texas have been discovered, and intensive sampling of moths using sex pheromone-baited traps has provided a framework to describe migratory patterns (Nagoshi et al. 2012, 2014, 2015). Model simulations have been developed to help in the prediction of inter-annual variability of fall armyworm patterns including those in response to climate change and adoption of transgenic crop cultivars (Westbrook et al. 2016; Westbrook et al. 2019). Within the last 5 years, this species has invaded Africa (Goergen et al. 2016), India (Sharanabasappa et al. 2018), southeastern Asia (Li et al. 2019), and most recently Australia (FAO 2020).

Growers in Florida plant over 88,000 ha of vegetables, including over 15,000 ha of fresh market sweet corn in southern Florida counties (USDA/NASS 2017). The crop season occurs from October to May of the following year in the southern counties (Ozores-Hampton et al. 2017) and although fall armyworm is considered a serious pest in some crops, it is effectively controlled in commercial fields using insecticides (Nuessly and Webb 2017). Fall armyworm populations from overwintering areas in southern Florida move into secondary source areas located in northern Florida by April and May (Pair and Westbrook 1995). In these areas of Florida, over 10,000 ha of vegetable crops, primarily potatoes (Solanum tuberosum L.) and cabbage (Brassica oleracea L. var. capitata) are grown during January to May (Elwakil and Mossler 2016; USDA/NASS 2017). Although fall armyworm is not a pest in these crops, resident and migrating populations are present in most vegetable production areas in the state.

Many vegetable growers plant cover crops either before or after their main crop is harvested, including grass, cereal, temperate and tropical legumes, and brassica plant species (Newman et al. 2014; Snapp et al. 2005). Improving soil conditions (Cherr et al. 2006, 2007; Wang et al. 2005), suppressing weed populations (Adler and Chase 2007; Cho et al. 2015; Collins et al. 2008; Morris et al. 2015; Mosjidis and Wehtje 2011), and reducing plant parasitic nematode densities (Bhan et al. 2010; Braz et al. 2016; Crow et al. 2001; Gallaher and McSorley 1993) are some of the benefits growers realize by planting cover crops. Many Florida growers plant cover crops such as corn (Zea mays L.) for livestock forage or sorghum-sudangrass [Sorghum bicolor (L.) Moench] to increase soil organic matter. Sorghum-sudangrass is a warm-season annual grass hybrid that is used as a green manure cover crop following harvest of winter vegetables (Newman et al. 2014; Vendramini et al. 2015).
However, cover crop plants can also influence the size of pest insect populations. For example, Spodoptera litura (F.) develops well on certain plants such as sesbania (Sesbania roxburghii Merr.), rapeseed (Brassicae campestris L. variety chinensis) and sunn hemp (Crotalaria juncea L.) and can develop large populations that then infest surrounding vegetable and row crops (Tuan et al. 2014). On the other hand, fall armyworm develops well on certain grass cover crops such as corn and sorghum-sudangrass, thereby increasing their populations to either infest adjoining crops or migrate northward (Meagher et al. 2004; Pair and Westbrook 1995). For areawide management of this pest, planting of alternate cover crops may reduce migrating populations.

Studies by Meagher et al. (2004) showed that sunn hemp and cowpea [Vigna unguiculata (L.) Walpers spp. unguiculata] have potential to reduce areawide populations of fall armyworm. Sunn hemp is a warm-season legume that is used in alternation with vegetable crops (Mansoer et al. 1997; Wang et al. 2015). Cowpea is a warm-season annual legume that alone or mixed with sorghum-sudangrass can be used as a cover crop or intercrop with vegetables (Cho et al. 2012; Harrison et al. 2014; Hödtke et al. 2016). Our first objective in these experiments was to compare population densities of fall armyworm in field plots composed of corn, sorghumsudangrass, sunn hemp, or cowpea. The earlier field studies were in northern Florida in an area where fall armyworm doesn't overwinter (Meagher et al. 2004). We wanted to use multi-year studies to compare cover crops in a location with overwintering populations (southern Florida), where overwintering populations may be present in some years (central Florida), and where fall armyworm populations are clearly migratory (northwest Florida). Since we expected sunn hemp to effectively reduce fall armyworm survival, our second objective was to compare larval feeding on different sunn hemp germplasm lines (Morris and Antonious 2013; Wang et al. 2006) in laboratory bioassays to determine the variability of larval weight gain and mortality.

\section{Materials and methods \\ Cover crop plants}

Cover crops were planted at three different locations in different years to compare fall armyworm numbers among the plant types. Treatments were located at the University of Florida Institute of Food and Agricultural Sciences (UF/IFAS) Everglades Research and Education Center, Belle Glade, Florida in 2011, the UF/IFAS North Florida Research and Education Center, Quincy, Florida in 2011 and 2012, and at the UF/IFAS Plant Science Research and Education Unit, Citra, Florida in 2012 and 2013 (Table 1). The experimental design at all 
Table 1 Location, county, coordinates, year(s) of study, plot size, and cover crop plants used for the field experiments, 2011-2013

\begin{tabular}{|c|c|c|c|c|}
\hline Location & County; Coordinates & Year(s) & Plot Size & Covers (seeding rate) \\
\hline Belle Glade & $\begin{array}{l}\text { Palm Beach } \\
\text { N 26.657, W- } 80.63\end{array}$ & 2011 & 12 rows $\times 30.5 \mathrm{~m}$ & SSG (4 seeds), SH (7), CP (7), fallow (unmanaged) \\
\hline Citra & $\begin{array}{l}\text { Marion } \\
\text { N 29.41, W - } 82.173\end{array}$ & $\begin{array}{l}2012 \\
2013 \\
2018\end{array}$ & $\begin{array}{l}8 \text { rows } \times 15.24 \mathrm{~m} \\
12 \text { rows } \times 15.24 \mathrm{~m} \\
6 \text { rows } \times 15.24 \mathrm{~m}\end{array}$ & $\begin{array}{l}\text { corn (6), SSG (6), SH (3), CP (4) } \\
\text { corn (3), SSG (9), SH (12), 50:50 mix of SSG and SH (12) } \\
\text { SSG (0.68 kg), SSG }(0.34 \mathrm{~kg})+\text { SH ( } 0.34 \mathrm{~kg}), \text { SSG } \\
(0.34 \mathrm{~kg})+\text { buckwheat }(0.91 \mathrm{~kg}) \text {, SSG }(0.34 \mathrm{~kg})+\text { millet } \\
(0.23 \mathrm{~kg})\end{array}$ \\
\hline Quincy & $\begin{array}{l}\text { Gadsden } \\
\text { N } 30.546, \text { W }-84.599\end{array}$ & $\begin{array}{l}2011 \\
2012\end{array}$ & $\begin{array}{l}8 \text { rows } \times 30.5 \mathrm{~m} \\
10 \text { rows } \times 15.24 \mathrm{~m}\end{array}$ & $\begin{array}{l}\text { SSG (4), SH (7), cowpea (7), fallow (unmanaged) } \\
\text { corn (1.25), SSG (4), SH (6), CP (6) }\end{array}$ \\
\hline
\end{tabular}

All seed rates are number of seeds in $30.5 \mathrm{~cm}$. In 2018, seeding rate is weight of seed per plot. CP: cowpea, SSG: sorghum-sudangrass, SH: sunn hemp

locations was a randomized complete block with 4 cover crop treatments, 4 blocks (replications), and plots were planted on $91.4 \mathrm{~cm}$ row centers. All plots were treated by pre-plant herbicides at locally recommend rates; after planting no pesticides were applied. Plots at Citra were irrigated with overhead irrigation throughout the season. Sunn hemp seed was an unknown germplasm (variety not stated) from South Africa (purchased from Petcher Seeds, Fruitdale, Alabama, USA), and was mixed with a cowpea-type Rhizobium inoculum before planting. Sorghum-sudangrass seed was Forage First Sudax SX-17 Sorghum x Sudangrass hybrid (Forage First, LaCrosse, Wisconsin, USA; now sold by Forage Genetics International, Nampa, Idaho, USA). Cowpea seed was 'Iron \& Clay' and was purchased through local distributors and was mixed with a cowpea-type Rhizobium inoculum, also purchased at a local distributor, before planting.

The Belle Glade plots were planted 5 July 2011 and treatments consisted of sorghum-sudangrass, sunn hemp, cowpea, and a fallow treatment (prepared but nothing planted and left unmanaged). The Quincy 2011 trial, planted 7 July, contained the same four treatments. The Quincy 2012 trial, planted 12 June, contained plots of corn (DKC 66-94 RR2, DeKalb Genetics Corp., DeKalb, Illinois, USA), sorghum-sudangrass, sunn hemp, and cowpea. The Citra 2012 trial, planted 3 July, contained corn ('Trucker's Favorite', purchased through a local distributor), sorghum-sudangrass, sunn hemp, and cowpea. Corn replaced fallow treatments because discussions with local growers indicated that it was used commonly as a cover crop to produce forage. The Citra 2013 trial, planted 11 June, contained corn ('Trucker's Favorite'), sorghum-sudangrass, sunn hemp, and a mix of sorghumsudangrass and sunn hemp at a 50:50 by volume. Further discussions with growers indicated that the price of sunn hemp was a consideration in cover crop choice, therefore mixing with sorghum-sudangrass would reduce the price. More specific information about the locations and plots are in Table 1.
Fall armyworm larvae were counted in each plot by randomly selecting 3 sites per plot (row number by number of paces). Instead of using a long tape measure, the number of paces along the plot row was calculated. For example, if the plot row was 70 paces long, a random number from 1 to 69 was chosen along with the randomly selected row. Plants were thoroughly searched for the presence of naturally-occurring larvae along onemeter row at each site. When larvae were discovered, they were placed in diet cups with plant material and transported back to the laboratory for parasitoid emergence following the methods of Meagher et al. (2016). Larval fate included finishing development and becoming a moth (live), dying due to unclassified circumstances such as disease or handling (dead), or being parasitized and producing an adult parasitoid.

The Belle Glade 2011 trial was only sampled 2 and 24 August due to the presence of earwig predators and the lack of a fall armyworm population in the plots (see Results). The Quincy 2011 trial was sampled 16 August, 6 and 27 September. The Quincy 2012 trial was sampled 12, 20, and 27 July and 2 August. The Citra 2012 trial was sampled 3, 9, 17, 24, and 31 August, and 11 and 21 September. The Citra 2013 trial was sampled 30 July, and 6, 15, and 23 August; only 2 sites per plot were selected in this trial.

Additional cover crop plants were used in the Citra 2018 trial because there was local acceptance for using buckwheat (Fagopyrum esculentum Moench) and pearl millet [Cenchrus americanus (L.) Morrone]. A randomized complete block design of 4 treatments and 4 blocks compared fall armyworm populations in plots with sorghum-sudangrass alone, sorghum-sudangrass + sunn hemp, sorghum-sudangrass + buckwheat, and sorghum-sudangrass + pearl millet. All seed was purchased from Petcher Seeds in June (Fruitdale, Alabama, USA) and planted 25 June. In each plot, a 1-m row was randomly selected (row number, number of paces) and all plants in that row were removed. The number of 
fall armyworm-injured sorghum-sudangrass plants were divided by the total number of sorghum-sudangrass plants to calculate the percent sorghum-sudangrass plants infested. Sunn hemp and buckwheat plants were not infested, and no larvae were recovered. Young millet plants were difficult to separate from young sorghumsudangrass plants, therefore the percent infested calculation for that treatment is based on all plants in the row. Plots were sampled 26 July, 6 August, and 14 August 2018.

\section{Border row plants}

The experiment in 2017 in Citra was designed to test the hypothesis that corn could be protected from fall armyworm injury by planting border rows of either sorghum-sudangrass or sunn hemp next to the corn. A randomized complete block design of 4 treatments and 4 blocks compared fall armyworm populations in 2 rows of corn ('Trucker's Favorite', purchased through a local distributor; planted 18 July) that had two rows of either sunn hemp alone or a mixture with sorghum-sudangrass $(25,50$, or $75 \%$ of the mixture) planted on 5 July on both sides. The 6-row $\times 15.24 \mathrm{~m}$ plots had either sunn hemp (0.68 kg), sunn hemp $(0.17 \mathrm{~kg})+$ sorghum-sudangrass $(0.51 \mathrm{~kg})$, sunn hemp $(0.34 \mathrm{~kg})+$ sorghum-sudangrass $(0.34 \mathrm{~kg})$, or sunn hemp $(0.51 \mathrm{~kg})+$ sorghum-sudangrass $(0.17 \mathrm{~kg})$ planted. In each plot, a $1-\mathrm{m}$ row was randomly selected (row number, number of paces) and all corn plants in that row were removed. The number of fall armyworm-injured plants were divided by the total number of plants to calculate the percent corn plants infested. The four border rows were sampled in the same way, randomizing row number plus number of paces. Percent infested plants (sunn hemp or sorghum-sudangrass) and number of larvae collected were documented. Samples were taken 3 August, 14 August, and 28 August 2017.

\section{Feeding study}

Seventeen lines of sunn hemp germplasm seeds were obtained from the USDA-ARS Plant Genetic Resources Conservation Unit, Griffin, Georgia, and were grown in 3.8-L pots in a greenhouse at ambient temperature. Plants were fertilized weekly with Miracle-Gro ${ }^{\circledR}$ 15-30-15 plant food (Marysville, Ohio, USA). No pesticides were applied to the plants. Leaves from plants aged ca. $6 \mathrm{wk}$. old were placed in rearing tray cells (BIO-RT-32 cell, Frontier, Newark, Delaware, USA) on top of Whatman No. 1 filter paper that was cut to fit and moistened with $0.3 \mathrm{~mL}$ deionized water. A corn strain fall armyworm colony ( $<1$ year old) collected from sweet corn in southern Florida (Hendry Co.) was used in the feeding study. Culture procedures followed Meagher et al. (2011). Neonates were individually added to the cells using a camel hair's brush. Cells were covered with gas permeable adhesive tabs (BIO-CV-4, Frontier, Newark, Delaware, USA), and each of the 3 replications contained 16 cells (16 neonates) per sunn hemp line. Trays were kept in an environmental chamber set at $24.8{ }^{\circ} \mathrm{C}, 70 \% \mathrm{RH}$, and $13 \mathrm{~h} / 11 \mathrm{~h}$ light/ dark photoperiod. After $5 \mathrm{~d}$, moisture and plant material were checked and replaced as needed, respectively. Larval mortality (defined as not moving after touching with a camel hair's brush) was calculated for each rep by the formula: (number of dead larvae/16) $\times 100$. Larval weights (Sartorius Model Precision Balance BP221S, Göttingen, Germany) were recorded after 9 days.

\section{Statistics}

All analyses were conducted using SAS (SAS 9.4, SAS Institute 2012). All data were first analyzed using BoxCox (PROC TRANSREG) and PROC UNIVARIATE to find the optimal normalizing transformation (Osborne 2010). Since many numbers were zero, 0.1 was added before transformation. Fall armyworm numbers in the field studies were analyzed using PROC GLIMMIX, with cover crop treatment as the fixed variable and date and block as the random variables. In all analyses LSMEANS with an adjusted Tukey test was used to separate variable means. Each location and year were analyzed separately.

Since relatively low numbers of fall armyworm were collected and returned to the laboratory for parasitoid emergence, cover crop treatment differences were compared using a randomized complete block design in PROC GLIMMIX, with treatment as the fixed variable and location as the random variable.

The feeding study was analyzed using a nested design (16 larvae per replication) in PROC GLIMMIX, with germplasm line as the fixed variable and replication within germplasm line as the random variable. Mortality was analyzed as a randomized complete block in PROC GLIMMIX with germplasm line as the fixed variable and replication as the random variable.

\section{Results \\ Cover crop plots}

No fall armyworm larvae were found at the Belle Glade 2011 trial, likely due to the presence of Doru taeniatum (Dohrn) (Dermaptera: Forficulidae). Samples taken 24 August showed that sorghum-sudangrass contained more earwigs than sunn hemp or cowpea plants $(16.5 \pm 2.1,2.25 \pm 0.75,0.75 \pm 0.48$, respectively; $\left.F_{2,6}=52.1, p=0.0002\right)$. Other insects and weeds were found in the plots. The sunn hemp plots by September attracted large numbers of the green June beetle, Cotinus nitida (L.) (Coleoptera: Scarabaeidae). The cowpea plots contained noticeable populations of Hawaiian beet webworm, Spoladea recurvalis (F.) (Lepidoptera: Crambidae) 
Table 2 Number of fall armyworm larvae per meter row in different cover crop plots, 2011, 2012, 2013, and 2018, Quincy and Citra, Florida

\begin{tabular}{|c|c|c|}
\hline Location/year & Treatment & Fall armyworm per meter row ${ }^{a}$ \\
\hline \multirow[t]{5}{*}{ Quincy 2011} & Sorghum-sudangrass & $1.0 \pm 0.59 \mathrm{a}$ \\
\hline & Cowpeas & $0.08 \pm 0.08 \mathrm{a}$ \\
\hline & Sunn hemp & $0 \pm 0 b$ \\
\hline & Fallow & $0 \pm 0 b$ \\
\hline & & $F_{3,9}=4.73, P=0.0302$ \\
\hline \multirow[t]{5}{*}{ Quincy 2012} & Corn & $1.21 \pm 0.36 \mathrm{a}$ \\
\hline & Sorghum-sudangrass & $0.65 \pm 0.13 \mathrm{a}$ \\
\hline & Sunn hemp & $0.08 \pm 0.06 b$ \\
\hline & Cowpeas & $0.02 \pm 0.02 b$ \\
\hline & & $F_{3,54}=17.31, P<0.0001$ \\
\hline \multirow[t]{5}{*}{ Citra 2012} & Corn & $1.71 \pm 0.28 \mathrm{a}$ \\
\hline & Sorghum-sudangrass & $0.73 \pm 0.2 b$ \\
\hline & Sunn hemp & $0.05 \pm 0.03 c$ \\
\hline & Cowpeas & $0.01 \pm 0.01 \mathrm{c}$ \\
\hline & & $F_{3,91}=44.92, P<0.0001$ \\
\hline \multirow[t]{5}{*}{ Citra 2013} & Corn & $2.875 \pm 1.02 \mathrm{a}$ \\
\hline & Sorghum-sudangrass & $1.1875 \pm 0.83 b$ \\
\hline & Mix & $0.375 \pm 0.25 b$ \\
\hline & Sunn hemp & $0.125 \pm 0.06 b$ \\
\hline & & $F_{3,54}=7.46, P=0.0003$ \\
\hline \multirow[t]{5}{*}{ Citra 2018} & Sorghum-sudangrass + millet & $4.7 \pm 2.4 \mathrm{a}$ \\
\hline & Sorghum-sudangrass + buckwheat & $1.8 \pm 0.08 \mathrm{a}$ \\
\hline & Sorghum-sudangrass + sunn hemp & $1.7 \pm 0.7 \mathrm{a}$ \\
\hline & Sorghum-sudangrass & $1.5 \pm 0.5 a$ \\
\hline & & $F_{3,38}=0.51, P=0.6755$ \\
\hline
\end{tabular}

Means followed by the same letter in each location/year are not significantly different, $P>0.05$

a Data in all experiments except Citra 2018 were transformed using $\mathrm{Y}^{-0.5}$. Data in Citra 2018 was transformed using $\mathrm{Y}^{-0.25}$

and several mirid and pentatomid species (not identified) (data not shown). Finally, by September all plots contained spiny pigweed, Amaranthus spinosus L., especially the fallow plots.

For the other locations, relatively low numbers of fall armyworm larvae were found in all plots, with an average of $0.25,0.50,0.626,1.14$, and 2.38 larvae per meter row for Quincy 2011, 2012, Citra 2012, 2013, and 2018, respectively (Table 2 ). In the only trial where corn was not planted (Quincy 2011), sorghum-sudangrass had more larvae than the other three treatments. However, this was from only one sample date (16 August), as all other sampling found no larvae. In the other trials, corn plots contained relatively high numbers of larvae per meter row (Table 2). Sorghum-sudangrass contained as many larvae as corn in Quincy 2012, but fewer in Citra 2012 and 2013. This cover crop treatment generally had more larvae than both sunn hemp and cowpea plots, although statistically similar to both covers in Quincy 2011. Sorghum-sudangrass contained numerically but not statistically higher numbers of larvae than the sunn hemp and sunn hemp + sorghum-sudangrass mixed plots in 2013.

The trial at Citra 2018 contained plots of sorghumsudangrass alone, or intercropped with sunn hemp, buckwheat, or millet. A total of 112 larvae were collected from the 4 treatments across 3 dates, with more larvae found during the July sampling (82) than the 2 August samples (22 and 8 ). Numerically more larvae were found in sorghum-sudangrass + millet plots, but this difference was not significant (Table 2). Percent infested plants was above $70 \%$ and was similar across cover treatments (sorghum-sudangrass + millet, $89.5 \pm 3.7 \%$, sorghum-sudangrass + buckwheat, $79.5 \pm 9.7 \%, \quad$ sorghum-sudangrass + sunn hemp, $77.8 \pm 9.6 \%$, and sorghum-sudangrass, $\left.73.4 \pm 8.8 \% ; F_{3,38}=0.51, p=0.6755\right)$.

\section{Larval parasitism}

Fall armyworm larvae from corn (284), sorghum-sudangrass (130) and sunn hemp plots (19) during Quincy 2011 
Table 3 Number of fall armyworm larvae per meter row and percent infested plants for corn and cover plants in different mixtures $(25,50$, or $75 \%)$ of border row plots, 2017 , Citra, Florida

\begin{tabular}{lllll}
\hline Treatment & Number of larvae in corn ${ }^{\mathbf{a}}$ & Percent infested corn plants ${ }^{\mathbf{b}}$ & \begin{tabular}{l} 
Number of larvae in $_{\text {cover plants }^{\mathbf{c}}}$ \\
\hline SH
\end{tabular} Percent infested cover plants $^{\mathbf{d}}$ \\
SH 25, SSG 75 & $0.667 \pm 0.284 \mathrm{a}$ & $61.3 \pm 10.3 \mathrm{a}$ & $0.0 \pm 0.0 \mathrm{~b}$ & $11.9 \pm 4.5 \mathrm{a}$ \\
SH 50, SSG 50 & $0.667 \pm 0.284 \mathrm{a}$ & $48.3 \pm 11.1 \mathrm{a}$ & $0.5 \pm 0.23 \mathrm{ab}$ & $30.9 \pm 9.0 \mathrm{a}$ \\
SH 75, SSG 25 & $2.08 \pm 1.07 \mathrm{a}$ & $43.9 \pm 9.0 \mathrm{a}$ & $0.75 \pm 0.579 \mathrm{a}$ & $26.2 \pm 5.0 \mathrm{a}$ \\
& $F_{3,39}=0.31, p=0.8214$ & $55.7 \pm 10.0 \mathrm{a}$ & $0.583 \pm 0.193 \mathrm{a}$ & $27.9 \pm 7.0 \mathrm{a}$ \\
& $F_{3,39}=0.82, p=0.4914$ & $F_{3,39}=3.02, p=0.0410$ & $F_{3,39}=1.81, p=0.1614$ \\
\hline
\end{tabular}

$\mathrm{SH}=$ sunn hemp, $\mathrm{SSG}=$ sorghum-sudangrass

a Data transformed using $\mathrm{Y}^{0.25}$

b Data transformed using $\mathrm{Y}^{0.75}$

c Data transformed using $Y^{1.25}$. Means followed by the same letter are not significantly different, $P>0.05$

d Data transformed using $\mathrm{Y}^{0.25}$

and 2012 and Citra 2012 and 2013 were brought back to the laboratory and held for parasitoid emergence. Only 8 larvae were recovered from the cowpea plots and that information was not included in the analysis. Larvae collected in Citra 2017 and 2018 were not returned to the laboratory. Overall, $38 \%$ of the larvae completed development, with a higher percentage of those collected in the sorghum-sudangrass plots $(61.6 \pm 0.6 \%)$ than the sunn hemp plots $(15.0 \pm 7.6 \%)$, while the percentage from the corn plots was intermediate $\left(38.3 \pm 5.6 \% ; \mathrm{F}_{2,4}=18.0\right.$,

Table 4 Larval weight and mortality of fall armyworm after 9 days feeding on leaves of different sunn hemp germplasm

\begin{tabular}{|c|c|c|c|c|}
\hline PI No & Identifier $^{\mathrm{a}}$ & Origin $^{a}$ & $\begin{array}{l}\text { Larval wt. (mg) } \\
(9 \mathrm{~d})^{\mathrm{b}}\end{array}$ & Mortality (\%) \\
\hline 468956 & 'Tropic Sun' & USA & $32.6 \pm 3.16$ & $0.0 \pm 0.0 c$ \\
\hline 561720 & $\mid A C-1$ & Brazil & $25.1 \pm 3.66$ & $8.4 \pm 2.1 \mathrm{ab}$ \\
\hline 314239 & Col No 524 & Former Soviet Union & $24.1 \pm 3.28$ & $6.3 \pm 3.6 \mathrm{ab}$ \\
\hline 426626 & Sanni K-98 & Pakistan & $22.8 \pm 2.33$ & $6.3 \pm 3.6 \mathrm{ab}$ \\
\hline 250487 & K681 & India & $21.1 \pm 2.43$ & $6.3 \pm 3.6 \mathrm{ab}$ \\
\hline 346297 & n.a & India & $18.9 \pm 1.76$ & $0.0 \pm 0.0 c$ \\
\hline 250485 & K679 & India & $18.9 \pm 3.17$ & $10.4 \pm 7.5 \mathrm{ab}$ \\
\hline 391567 & T'ai-yang-ma & South Africa & $18.7 \pm 1.56$ & $12.5 \pm 3.6 \mathrm{a}$ \\
\hline 'AU Golden'd & n.a & USA & $17.7 \pm 1.49$ & $0.0 \pm 0.0 c$ \\
\hline $207657^{e}$ & n.a & Sri Lanka & $16.8 \pm 1.63$ & $8.4 \pm 2.1 \mathrm{ab}$ \\
\hline $322377^{f}$ & |R| 2473 & Brazil & $16.6 \pm 1.45$ & $14.6 \pm 4.2 \mathrm{a}$ \\
\hline 'Tropic Sun'9 & n.a & USA & $16.3 \pm 1.58$ & $8.4 \pm 5.5 a b$ \\
\hline Tillage Sunn $^{\mathrm{TMh}}$ & n.a & India & $15.3 \pm 1.54$ & $4.2 \pm 4.2 b c$ \\
\hline South Africa' & n.a & South Africa & $14.8 \pm 1.58$ & $12.5 \pm 0 \mathrm{a}$ \\
\hline 337080 & n.a & Brazil & $13.9 \pm 1.81$ & $8.4 \pm 2.1 \mathrm{ab}$ \\
\hline 219717 & n.a & Myanmar & $11.5 \pm 1.01$ & $8.4 \pm 5.5 \mathrm{ab}$ \\
\hline 250486 & K680 & India & $11.4 \pm 1.4$ & $10.4 \pm 7.5 \mathrm{ab}$ \\
\hline
\end{tabular}

a Wang et al. (2006); Morris and Antonious (2013)

${ }^{b}$ Data were transformed using $\mathrm{Y}^{0.25}$. Means were not different among germplasm lines, $F=0.56 ; \mathrm{df}=16,34 ; P=0.8899$

${ }^{c}$ Data were transformed using $Y^{0.25}$. Means followed by the same letter are not significantly different, $F=2.7 ; \mathrm{df}=16,32 ; P=0.0083$

d Purchased from Petcher Seeds, Fruitdale, Alabama, USA

e Accession selected to create 'AU Durbin'

' Accession selected to create 'AU Golden'

$g$ Purchased from Molokai Seed Co., Kaunakakai, Hawaii, USA

h Germplasm from Hancock Seed Co., Dade City, Florida, USA

' Unknown germplasm (VNK) purchased through Petcher Seeds, Fruitdale, Alabama 
$P=0.0100$ ). Alternatively, $31 \%$ of the collected larvae died due to disease or handling, with a higher percentage from the sunn hemp plots $(56.7 \pm 23.3 \%)$ than the corn $(19.4 \pm 3.8 \%)$ or sorghum-sudangrass plots $(17.2 \pm 2.2 \%)$. However, this difference among cover treatments was not significant $\left(\mathrm{F}_{2,4}=2.9, P=0.1676\right)$. Parasitism due to all species was not different among treatments and averaged 30\%. The egg-larval species Chelonus insularis Cresson (Hymenoptera: Braconidae) emerged from larvae at an average of $15 \%$, and was collected at a higher percentage from larvae collected in the corn plots $(32.5 \pm 8.5 \%)$ than those in the sunn hemp plots $(3.3 \pm 3.3 \%)$, while emergence from larvae in the sorghum-sudangrass plots was intermediate $\left(9.8 \pm 3.8 \% ; \mathrm{F}_{2,4}=7.2, P=0.0470\right)$. The larval endoparasitoid Cotesia marginiventris (Cresson) (Hymenoptera: Braconidae) averaged $10 \%$ parasitism, while other species such as Aleiodes laphygmae (Viereck) (Hymenoptera: Braconidae), Meteorus spp. (Hymenoptera: Braconidae), Euplectrus platyhypenae Howard (Hymenoptera: Eulophidae) and unidentified species of Tachinidae made up the last $5 \%$ parasitism.

\section{Border row plants}

There was no difference in the number of larvae collected or percent corn plants infested, whether sunn hemp alone or a mixture of sunn hemp and sorghum-sudangrass was planted adjacent to the corn in the Citra 2017 trial (Table 3). More larvae (29) were collected in corn during the first sampling date ( 2 weeks after planting) than during the last sampling date (2). In the cover crop plants, fewer larvae were found in sunn hemp compared to mixtures with sorghum-sudangrass (Table 3). Between 40 and a little over $60 \%$ of corn plants were infested by fall armyworm, compared to less than $31 \%$ of the cover plants.

\section{Feeding studies}

Fall armyworm larvae were fed leaves from different sunn hemp germplasm for 9 days, with an overall weight of $18.7 \pm 0.56 \mathrm{mg}$. The overall model was not significant $\left(F_{16,34}=0.56 ; P=0.8899\right)$, although numerically larvae feeding on PI 468,956 (32.6 mg) were heavier than larvae feeding on PI 250,486 and PI 219,717 (Table 4). Larval mortality ranged from 0 to $14.6 \%$, with $13 / 17$ lines having similar percentages (Table 4).

\section{Discussion}

Sorghum-sudangrass is a common cover crop planted after spring vegetables in areas of Florida which contain overwintering populations of fall armyworm and in areas known as stepping-stone nurseries or secondary source sites (Pair and Westbrook 1995). These secondary source sites can produce large numbers of migratory moths that continue northward in the spring and summer infesting much of the central and northeastern U.S. Our experiments were conducted in different locations and using different cover crop plants such as sunn hemp, cowpeas, corn, buckwheat, and pearl millet to determine appropriate replacements for sorghum-sudangrass.

Unfortunately, the trial at an overwintering site in Belle Glade produced no information for the use of cover crops in fall armyworm management, as no fall armyworm larvae were found in the treatment plants. The lack of larvae in the whorls was probably due to the earwig $D$. taeniatum, which was found in large numbers in sorghum-sudangrass plants because this predator hides in the whorls of grasses and females raise their young in these locations (Jones et al. 1988). This and related Doru spp. are well known predators of S. frugiperda in central and South America (Castillejos et al. 2001; Jones et al. 1988; Sueldo et al. 2010). Therefore, it isn't known if fall armyworm populations that survive in areas of continuous generations are affected by cover crop plants or how these particular cover crop plants develop under growing conditions in southern Florida.

The Quincy 2011 trial had only one date where fall armyworm larvae were collected. Heavy summer rains after the initial sample date may have contributed to severe reductions in populations, as dislodgment and drowning are important mortality factors for young larvae (Varella et al. 2015). As expected in the other trials, fewer fall armyworm larvae were found on sunn hemp and cowpea plants than on sorghum-sudangrass or corn. The fall armyworm population found on sunn hemp was 89,94 , and $90 \%$ smaller than that found on sorghumsudangrass for the Quincy 2012, Citra 2012, and Citra 2013 locations, respectively. This percent reduction in population levels compares favorably to reductions of 83 and 95\% in plots from an earlier study (Meagher et al. 2004). Those larvae found on sunn hemp were exposed to parasitism at the same level as larvae found on the other cover crop treatments. For cowpea, the difference in fall armyworm numbers compared with sorghum-sudangrass is even more dramatic, with plots in our study and that of Meagher et al. (2004) all showing reductions of over $96 \%$. Cowpea is attractive to neonate S. frugiperda (Carroll et al. 2008), but growth is slow and there is high mortality after establishment (Meagher et al. 2004). However, several other insect pests (Miridae, Pentatomidae) were found in our trials, which possibly would negate its positive effects for fall armyworm areawide management. Addition of buckwheat and pearl millet to sorghumsudangrass did not reduce fall armyworm infestation, and in fact over 2.5 times more larvae were found in the mixture with pearl millet than sorghum-sudangrass alone. 
Earlier studies by Pair and Westbrook (1995) and Meagher et al. (2004) suggested that sorghum-sudangrass cover crops could produce 320 million adults/ha if $50 \%$ of the larvae survived to adulthood. The amount of sorghum-sudangrass grown as a cover crop in the southern Florida sweet corn area isn't known, but over 15,000 ha of sweet corn were planted in 2015 (USDA/NASS 2017). If $1 / 4$ of the land is planted to a sorghum-sudangrass cover, then over 1.2 trillion adult moths are potentially produced ( 320 million adults per ha $\times 3750$ ha). These moths would be possible migrants in the spring or would be available for reinfestation of future crops; therefore, reductions of over $90 \%$ in areas grown to sunn hemp could reduce fall armyworm populations which would be helpful to areawide management.

New varieties of sunn hemp are now available to growers (Mosjidis 2014), therefore a comparison of fall armyworm feeding with the older varieties and potential breeding germplasm was needed. Larvae feeding on plants of PI 468956, the germplasm used to develop 'Tropic Sun' (Wang et al. 2006), were numerically the heaviest larvae and larval weight was similar to a previous study (Meagher et al. 2004). It's surprising that larvae feeding on plants produced from seed purchased as 'Tropic Sun' from Hawaii were half as small, although the difference was not significant. Larval weights from feeding on 'AU Golden' and on PI 322377, the germplasm line used to create this cultivar (Cho et al. 2016; Mosjidis 2014), were very similar to Tillage Sunn ${ }^{\mathrm{TM}}$, one of the other lines used in a Florida sunn hemp flowering study (Meagher et al. 2017). The line from South Africa that was used in the field trials in this study produced small larvae with relatively high levels of mortality, similar to work conducted in Brazil (Dias et al. 2016).

Diversifying corn agroecosystems with additional plant species has been a strategy to manage fall armyworm populations in subtropical and tropical areas of the Americas. Strategies either involve early planting of a specified cover crop species followed by no-till cultivation of the corn crop (Dias et al. 2016), no-till cultivation along with weedy plant seed mixtures or into already established natural weed associations (Altieri 1980; Altieri and Whitcomb 1980), or intercropping with other crop plants (Altieri 1980). These strategies generally achieve the goal of lower pest populations and higher natural enemy activity; however, they can be field-specific and have no areawide pest suppression benefit. Our attempt to protect a corn planting by border rows of sunn hemp plus mixes of sorghum-sudangrass in the Citra 2017 trial was unsuccessful. However, more research should be conducted using push-pull technology that repels fall armyworm from host plots while attracting them to border row plants (Midega et al. 2018).
Our strategy in temperate areas is to replace a conventionally-planted cover crop that is known to be a good host plant and instead plant one or more cover crop species, such as cowpeas and sunn hemp, that are not favorable hosts to fall armyworm. Sunn hemp has that potential as results from our study and others suggest it is a poor host for fall armyworm due to low weight gain, longer developmental times, and higher mortality than other cover crop species (Dias et al. 2016; Meagher et al. 2004). Sunn hemp also has additional benefits that will help it fit into the agricultural systems of the southeastern U.S. (Schomberg et al. 2007; Wang et al. 2008), including attracting a variety of Hymenopteran pollinators (Meagher et al. 2019, 2020). However, additional research is needed to determine the influence of cover crops on the population dynamics of fall armyworm and thereby the potential effect of changes in cover crop choice. In particular we need to determine the extent to which different cover crops serve as refuges for fall armyworm populations when cooler or warmer winters influence the size of the overwintering and secondary source areas (Garcia et al. 2017).

\section{Acknowledgements}

We thank the University of Florida employees of the Everglades Research and Education Center, Belle Glade, North Florida Research and Education Center, Quincy, and the University of Florida Plant Science Research and Education Unit, Citra, for their efforts in planting and maintaining the field plots. The technical support of Gaelin McLeod, American Conservation Experience, is appreciated.

\section{Authors' contributions}

The project was conceived by RLM, RNN, SJF, and JKW; data analyzed by RLM; manuscript written by RLM and RNN; DLW provided field plots at Quincy; JBM provided sunn hemp germplasm; JTB and AJR provided technical support; manuscript reviewed by all authors. All authors read and approved and the final manuscript.

\section{Funding}

This work was supported by the National Institute of Food and Agriculture, U.S. Department of Agriculture, under Agreement No. 2011-67003-30209. The use of trade, firm, or corporation names in this publication is for the information and convenience of the reader. Such use does not constitute an official endorsement or approval by the United States Department of Agriculture or the Agricultural Research Service of any product or service to the exclusion of others that may be suitable.

\section{Availability of data and materials}

The datasets during and/or analyzed during the current study available from the corresponding author on reasonable request.

\section{Declarations}

Ethics approval and consent to participate

No ethics approval or consent is needed.

\section{Competing interests}

The authors declare that they have no competing interests. 


\section{Author details}

${ }^{1}$ Insect Behavior and Biocontrol Research Unit, USDA-ARS CMAVE, 1700 SW 23rd Dr., Gainesville, FL 32608, USA. ${ }^{2}$ Department of Entomology, Pennsylvania State University, University Park, PA 16802, USA. ${ }^{3}$ Insect Control and Cotton Disease Research Unit, USDA-ARS SPARC, College Station, TX 77845-4966, USA. ${ }^{4}$ North Florida Research and Education Center, University of Florida, Quincy, FL 32351, USA. ${ }^{5}$ Plant Genetic Resources Conservation Unit, USDA-ARS, Griffin, GA 30223, USA. ${ }^{6}$ Entomology and Nematology Department, University of Florida, Gainesville, FL 32611, USA.

Received: 6 May 2021 Accepted: 14 December 2021

Published online: 03 January 2022

\section{References}

Adler MJ, Chase CA. Comparison of the allelopathic potential of leguminous summer cover crops: cowpea, sunn hemp, and velvetbean. HortScience. 2007:42:289-93.

Altieri MA. Diversification of corn agroecosystems as a means of regulating fall armyworm populations. Florida Entomol. 1980;63:450-6.

Altieri MA, Whitcomb WH. Weed manipulation for insect pest-management in corn. Environ Manag. 1980;4:483-9.

Bhan M, McSorley R, Chase CA. Effect of cropping system complexity on plantparasitic nematodes associated with organically grown vegetables in Florida. Nematropica. 2010;40:53-70.

Braman SK, Duncan RR, Engelke MC. Evaluation of turfgrass selections for resistance to fall armyworms (Lepidoptera: Noctuidae). HortScience. 2000;35:1268-70.

Braz GBP, Oliveira Jr RS, Crow WT, Chase CA. Susceptibility of different accessions of Crotalaria juncea to Belonolaimus longicaudatus. Nematropica. 2016:46:31-37.

Carroll MJ, Schmelz EA, Teal PEA. The attraction of Spodoptera frugiperda neonates to cowpea seedlings is mediated by volatiles induced by conspecific herbivory and the elicitor inceptin. J Chem Ecol. 2008;34:291-300.

Castillejos V, Garcia L, Cisneros J, Goulson D, Cave RD, Caballero P, Williams T. The potential of Chrysoperla rufilabris and Doru taeniatum as agents for dispersal of Spodoptera frugiperda nucleopolyhedrovirus in maize. Entomol Exp Appl. 2001;98:353-9.

Cherr CM, Scholberg JMS, McSorley R. Green manure as nitrogen source for sweet corn in a warm-temperature environment. Agronomy J. 2006:98:1173-80.

Cherr CM, Scholberg JMS, McSorley R, Mbuya OS. Growth and yield of sweet corn following green manure in a warm temperature environment on sandy soil. J Agron Crop Sci. 2007;193:1-9.

Cho AH, Hodges AW, Chase CA. Partial budget analysis of summer fallows for organic nutrient and weed management in Florida. HortTech. 2012:22:258-62

Cho AH, Chase CA, Treadwell DD, Koenig RL, Morris JB, Morales-Payan JP. Apical dominance and planting density effects on weed suppression by sunn hemp (Crotalaria juncea L.). HortScience. 2015;50:263-67.

Cho AH, Chase CA, Koenig RL, Treadwell DD, Gaskins J, Morris JB, MoralesPayan JP. Phenotypic characterization of 16 accessions of sunn hemp in Florida. Agronomy J. 2016;108:2417-24.

Collins AS, Chase CA, Stall WM, Hutchinson CM. Optimum densities of three leguminous cover crops for suppression of smooth pigweed (Amaranthus hybridus). Weed Sci. 2008;56:753-61.

Crow WT, Weingartner DP, Dickson DW, McSorley R. Effect of sorghum-sudangrass and velvetbean cover crops on plant-parasitic nematodes associated with potato production in Florida. J Nematol. 2001;33:285-8.

Dias AS, Marucci RC, Mendes SM, Moreira SG, Araújo OG, dos Santos CA, Barbosa TA. Bioecology of Spodoptera frugiperda (Smith, 1797) in different cover crops. Bioscience J. 2016;32:337-45.

Elwakil, WM, Mossler, M. Florida crop/pest management profile: cabbage. Univ. Florida, IFAS Ext., 2016;CIR1256,18p.

FAO. Global action for fall armyworm control. 2020; http://www.fao.org/fallarmyworm/monitoring-tools/faw-map/en/.

Gallaher RN, McSorley R. Population densities of Meloidogyne incognita and other nematodes following seven cultivars of cowpea. Nematropica. 1993:23:21-6.
Garcia AG, Godoy WAC, Thomas JMG, Nagoshi RN, Meagher RL. Delimiting strategic zones for the development of fall armyworm (Lepidoptera: Noctuidae) on corn in the State of Florida, based on thermal requirements and GIS modeling. J Econ Entomol. 2018;111:120-6.

Goergen G, Kumar PL, Sankung SB, Togola A, Tamò M. First report of outbreaks of the fall armyworm Spodoptera frugiperda (J E Smith) (Lepidoptera, Noctuidae), a new alien invasive pest in West and Central Africa. PLoS ONE. 2016;11:e0165632.

Harrison Jr. HF, Jackson DM, Thies JA, Fery RL, Smith JP. US-1136, US-1137, and US-1138 cowpea lines for cover crop use. HortScience. 2014;49:364-366.

Hoffman KM. Earwigs (Dermaptera) of South Carolina, with a key to the eastern North American species and a checklist of the North American fauna. Proc Entomol Soc Washington. 1987:89:1-14.

Hödtke M, Lopes de Almeida D, Köpke U. Intercropping of maize and pulses: an evaluation of organic cropping systems. Organic Agric. 2016;6:1-17.

Jones RW, Gilstrap FE, Andrews KL. Biology and life tables for the predaceous earwig, Doru taeniatum (Derm: Forficulidae). Entomophaga. 1988;33:43-54

Li XJ, Wu MF, Ma J, Gao BY, Wu QL, Chen AD, Liu J, Jiang YY, Zhai BP, Regan E, Chapman JW, Hua G. Prediction of migratory routes of the invasive fall armyworm in eastern China using a trajectory analytical approach. Pest Managem Sci. 2019;76:454-63.

Luttrell RG, Mink JS. Damage to cotton fruiting structures by the fall armyworm, Spodoptera frugiperda (Lepidoptera: Noctuidae). J Cotton Sci. 1999:3:35-44

Mansoer Z, Reeves DW, Wood CW. Suitability of sunn hemp as an alternative late-summer legume cover crop. Soil Sci Soc Am J. 1997;61:246-53.

Meagher RL, Nagoshi RN, Stuhl C, Mitchell ER. Larval development of fall armyworm (Lepidoptera: Noctuidae) on different cover crop plants. Florida Entomol. 2004;87:454-60.

Meagher RL, Nagoshi RN, Stuhl CJ. Oviposition choice of two fall armyworm (Lepidoptera: Noctuidae) host strains. J Insect Behav. 2011;24:337-47.

Meagher RL Jr, Nuessly GS, Nagoshi RN, Hay-Roe MM. Parasitoids attacking fall armyworm (Lepidoptera: Noctuidae) in sweet corn habitats. Biol Control. 2016:95:66-72

Meagher RL Jr, Nagoshi RN, Brown JT, Fleischer SJ, Westbrook JK, Chase CA. Flowering of the cover crop sunn hemp Crotalaria Juncea L. Hortscience. 2017:52:986-90.

Meagher Jr, RL, Watrous K, Fleischer SJ, Nagoshi RN, Brown JT, Bowers K, Miller N, Hight SD, Legaspi JC, Westbrook JK. Documenting potential sunn hemp pollinators in Florida. Environ Entomol. 2019;48(2):343-50.

Meagher Jr RL, Watrous KM, Fleischer SJ, Nagoshi RN, Brown JT, Westbrook JK. Comparison of bee composition in sunn hemp and other cover crops. Fla Entomol. 2020;103(4):419-24.

Midega CAO, Pittchar JO, Pickett JA, Hailu GW, Khan ZR. A climate-adapted push-pull system effectively controls fall armyworm, Spodoptera frugiperda (J E Smith), in maize in East Africa. Crop Prot. 2018;105:10-5.

Morris JB, Antonious GF. Glucose, stem dry weight variation, principal component and cluster analysis for some agronomic traits among 16 regenerated Crotalaria juncea accessions for potential cellulosic ethanol. J Environ Sci Health B. 2013:48:214-8.

Morris JB, Chase CA, Treadwell D, Koenig R, Cho A, Morales-Payan JP, Murphy T, Antonious GF. Effect of sunn hemp (Crotalaria juncea $\mathrm{L}$ ) cutting date and planting density on weed suppression in Georgia, USA. J Environ Sci Health B. 2015:50:614-21.

Mosjidis, JA. Sunn hemp cultivars capable of producing seed within the continental United States. 2014; United States Patent, US 8,680,369 B2.

Mosjidis JA, Wehtje G. Weed control in sunn hemp and its ability to suppress weed growth. Crop Prot. 2011;30:70-3.

Nagoshi RN, Meagher RL, Hay-Roe M. Inferring the annual migration patterns of fall armyworm (Lepidoptera: Noctuidae) in the United States from mitochondrial haplotypes. Ecol Evol. 2012;2:1458-67.

Nagoshi RN, Meagher RL, Hay-Roe M. Assessing the resolution of haplotype distributions to delineate fall armyworm (Lepidoptera: Noctuidae) migratory behaviors. J Econ Entomol. 2014;107:1462-70.

Nagoshi RN, Rosas-García NM, Meagher RL, Fleischer SJ, Westbrook JK, Sappington TW, Hay-Roe M, Thomas JMG, Murúa GM. Haplotype profile comparisons between Spodoptera frugiperda (Lepidoptera: Noctuidae) populations from Mexico with those from Puerto Rico, South America, and the United States and their implications to migratory behavior. J Econ Entomol. 2015;108:135-44. 
Newman, YC, Wright, DL, Mackowiak, C, Scholberg, JMS, Cherr, CM, Chambliss, CG. Cover crops. 2014; Univ. Florida, IFAS, Florida Coop. Ext. Serv. SS-AGR-66.

Nuessly, GS, Webb, SE. Insect management for sweet corn. UF/IFAS Entomology and Nematology Dept. 2017;ENY-472, http://edis.ifas.ufl.edu/pdffiles/ IG/IG15800.pdf.

Nuessly GS, Scully BT, Hentz MG, Beiriger R, Snook ME, Widstrom NW. Resistance to Spodoptera frugiperda (Lepidoptera: Noctuidae) and Euxesta stigmatias (Diptera: Ulidiidae) in sweet corn derived from exogenous and endogenous genetic systems. J Econ Entomol. 2007;100:1887-95.

Osborne J. Improving your data transformations: applying the Box-Cox transformation. Pract Assess Res Eval. 2010;15:12.

Ozores-Hampton, M, Kinessary, R, McAvoy, EJ, Raid, RN, Beuzelin, J. Chapter 17. Sweet corn production. Vegetable Production Handbook for Florida, 2017-2018. UF/IFAS Ext. Horticultural Sciences Dept. 2017;HS-737, http:// edis.ifas.ufl.edu/pdffiles/CV/CV13500.pdf.

Pair SD, Westbrook JK. Agro-ecological and climatological factors potentially influencing armyworm populations and their movement in the southeastern United States. Southwestern Entomol. 1995;18:101-18.

Pair SD, Raulston JR, Sparks AN, Westbrook JK, Douce GK. Fall armyworm distribution and population dynamics in the southeastern states. Florida Entomol. 1986;69:468-87.

Pair SD, Raulston JR, Westbrook JK, Wolf WW, Adams SD. Fall armyworm (Lepidoptera: Noctuidae) outbreak originating in the lower Rio Grande Valley, 1989. Florida Entomol. 1991;74:200-13.

Raulston JR, Pair SD, Sparks AN, Loera J, Pedraza FA, Palamon A, Ortega A, Ruiz Sanchez J, Marquez P, Rueles H, Perez J, Rodriguez R, Carrillo H, Archundia $R$, Herrera F. Fall armyworm distribution and population dynamics in the Texas-Mexico Gulf Coast area. Florida Entomol. 1986;69:455-68.

SAS Institute. SAS for Windows, 9.4. 2012; SAS Institute Inc., Cary, North Carolina.

Schomberg HH, Martini NL, Diaz-Perez JC, Phatak SC, Balkcom KS, Bhardwaj HL. Potential for using sunn hemp as a source of biomass and nitrogen for the Piedmont and Coastal Plain regions of the southeastern USA. Agron J. 2007:99:1448-57.

Sharanabasappa SE, Kalleshwaraswamy CM, Asokan R, Swamy HMM, Maruthi MS, Pavithra HB, Hegde K, Navi S, Prabhu ST, Goergen G. First report of the Fall armyworm, Spodoptera frugiperda (J E Smith) (Lepidoptera: Noctuidae), an alien invasive pest on maize in India. Pest Managem Hortic Ecosystem. 2018;24(1):23-9.

Snapp SS, Swinton SM, Labarta R, Mutch D, Black JR, Leep R, Nyiraneza J, O'Neil K. Evaluating cover crops for benefits, costs and performance within cropping system niches. Agron J. 2005;97:322-32.

Souza BHS, Bottega DB, da Silva AG, Boiça Júnior AL. Feeding non-preference by Spodoptera frugiperda and Spodoptera eridania on tomato genotypes. Revista Ceres Viçosa. 2013;60:21-9.

Sueldo MR, Bruzzone OA, Virla EG. Characterization of the earwig, Doru lineare, as a predator of larvae of the fall armyworm, Spodoptera frugiperda: a functional response study. J Insect Sci. 2010;10(38):10p.

Tuan SJ, Li NJ, Yeh CC, Tang LC, Chi H. Effects of green manure cover crops on Spodoptera litura (Lepidoptera: Noctuidae) populations. J Econ Entomol. 2014;107:897-905.

USDA/NASS. State agriculture overview for Florida. 2017; https://www.nass. usda.gov/Quick_Stats/Ag_Overview/stateOverview.php?state=FLORIDA.

Varella AC, Menezes-Netto AC, de Souza Alonso JD, Caixeta DF, Peterson RKD, Fernandes OA. Mortality dynamics of Spodoptera frugiperda (Lepidoptera: Noctuidae) immatures in maize. PLoS ONE. 2015;10(6): e0130437. https:// doi.org/10.1371/journal.pone.0130437.

Vendramini, J, Adesogan, A, Wasdin, J. Silage crops for dairy and beef cattle. 2015:Univ. Florida, IFAS, Florida Coop. Ext. Serv. SS-AGR-69.

Wang Q, Klassen W, Li Y, Codallo M, Abdul-Baki AA. Influence of cover crops and irrigation rates on tomato yields and quality in a subtropical region. HortScience. 2005;40:2125-31.

Wang ML, Mosjidis JA, Morris JB, Dean RE, Jenkins TM, Pederson GA. Genetic diversity of Crotalaria germplasm assessed through phylogenetic analysis of EST-SSR markers. Genome. 2006:49:707-15.

Wang K-H, McSorley R, Gallaher RN, Kokalis-Burelle N. Cover crops and organic mulches for nematode, weed and plant health management. Nematol. 2008;10:231-42.

Wang, Q, Li, YC, Klassen, W, Hanlon, Jr, EA. Sunn hemp - a promising cover crop in Florida. 2015; Univ. Florida, IFAS, Florida Coop. Ext. Serv. SL306.
Westbrook JK, Sparks AN. The role of atmospheric transport in the economic fall armyworm (Lepidoptera: Noctuidae) infestations in the southeastern United States in 1977. Florida Entomol. 1986;69:492-502.

Westbrook JK, Nagoshi RN, Meagher RL, Fleischer SJ, Jairam S. Modeling seasonal migration of fall armyworm moths. Int J Biometeorol. 2016;60:255-67.

Westbrook J, Fleischer S, Jairam S, Meagher R, Nagoshi R. Multigenerational migration of fall armyworm, a pest insect. Ecosphere. 2019;10(11):e02919.

\section{Publisher's Note}

Springer Nature remains neutral with regard to jurisdictional claims in published maps and institutional affiliations.
Ready to submit your research? Choose BMC and benefit from:

- fast, convenient online submission

- thorough peer review by experienced researchers in your field

- rapid publication on acceptance

- support for research data, including large and complex data types

- gold Open Access which fosters wider collaboration and increased citations

- maximum visibility for your research: over 100M website views per year

At BMC, research is always in progress.

Learn more biomedcentral.com/submissions 